\title{
Understanding the customer experience in the age of omni-channel shopping
}

\section{Comprendiendo la experiencia del cliente en la era de las compras omnicanal}

\author{
Ana Mosquera \\ Ph.D. candidate in the Marketing Department \\ (University of La Rioja) \\ Cristina Olarte Pascual \\ Associate Professor in the Department of Marketing \\ (University of La Rioja) \\ Emma Juaneda Ayensa \\ Professor in the Department of Economics and Business \\ (University of La Rioja)
}

Reception date: 19 April 2017

Review date: 20 June 2017

Published: 1 July 2017

To cite this article: Mosquera, A., Olarte Pascual, C. y Juaneda Ayensa , E. (2017): Understanding the customer experience in the age of omni-channel shopping, Icono 14, volumen 15 (2), pp. 166-185. doi: 10.7195/ri14.v15i2.1070 


\section{Abstract}

Omni-channel is one of the most important retail revolutions of recent years, impacting a variety of areas, such as marketing, retailing, communication or information systems. Omni-channel marketing refers to the brand strategy which integrate all channels available to create a seamless shopping experience that increase convenience and engagement during the customer journey. The aim of this study is to provide an overview of the state of the art of this phenomenon. Its main contributions are fourfold. First, it reduces the fuzziness of the term omni-channel, clearly demarcating the concepts of multi-, cross-, and omni-channel shopping. Second, it offers a consolidated overview of the current understanding of the omni-channel customer experience. Third, the proposed framework points to new lines of research related to omni-channel marketing. The theoretical and managerial implications of this hot topic are also discussed.

Key Words: Omni-channel - Customer experience - Omni-shopper - Customer journey - Interactive technologies - Engagement

\section{Resumen}

La omnicanalidad es una de las revoluciones más importantes en los últimos años en el comercio minorista, afectando a una variedad de áreas como el marketing, el comercio, la comunicación o los sistemas de información. El marketing omnicanal hace referencia a la estrategia de marca que integra todos los canales disponibles para crear una experiencia de compra sin fisuras que aumenta la conveniencia y el compromiso del cliente durante el proceso de compra. El objetivo de este estudio es proporcionar una visión general del estado del arte de este fenómeno con una cuádruple contribución. Primero, reduce la confusión del término omnicanal, demarcando claramente los conceptos multi-, cross y omnicanalidad. Segundo, ofrece una visión general de la actual experiencia del consumidor en un entorno omnicanal. Tercero, se presentan nuevas líneas de investigación relacionadas con el marketing omnicanal. Finalmente, se discuten las implicaciones teóricas y de gestión de este tema de actualidad.

Palabras clave: Omnicanalidad - Experiencia del consumidor - Comprador omnicanal - Jornada del cliente - Tecnologías interactivas - Compromiso 


\section{Introduction}

The omni-channel concept is perhaps one of the most important revolutions in business strategy in recent years, with both practical and theoretical implications (Bell, Gallino, \& Moreno, 2014; Brynjolfsson, Hu, \& Rahman, 2013; Piotrowicz \& Cuthbertson, 2014; Verhoef, Kannan, \& Inman, 2015b). Firms compete in global markets, and markets have been transformed by technology. Advances in information technology and communication have led to an increase in the number of retailing formats through which consumers can contact a company during their customer journey. In addition to traditional physical and online stores, new mobile channels (mobile devices, branded apps, social media, and connected objects) and touch-points have transformed the consumer buying process (Juaneda-Ayensa, Mosquera, \& Sierra Murillo, 2016; Melero, Sese, \& Verhoef, 2016; Picot-Coupey, Huré, \& Piveteau, 2016; Piotrowicz \& Cuthbertson, 2014; Verhoef et al., 2015b).

Although the term omni-channel first appeared six years ago (Rigby, 2011), the concept remains unclear, due to the indistinct use of the concepts multi-, cross-, and omni-channel in the literature (Beck \& Rygl, 2015; Klaus, 2013). While multi-channel refers to having a presence on several channels that then work separately, in an omni-channel environment, the channels work together, such that customers can use digital channels for research and experience the physical store in a single transaction process (Piotrowicz \& Cuthbertson, 2014). Because the channels are jointly managed, customers expect to have the same brand experience wherever and whenever they interact the company (Piotrowicz \& Cuthbertson, 2014).

This new term originated among business practitioners, but it has recently drawn attention in academia as well. The ways in which omni-channel retailing is changing consumer habits and shopping behavior have made it the third and current wave of retailing (Peltola, Vainio, \& Nieminen, 2015). Omni-channel management continues to be a big challenge for brands, because customers are more demanding and expect companies to provide them with a superior shopping experience during their customer journey. With the proliferation of mobile technologies and social media, this customer journey has become more complicated; the simultaneous use of different communication channels by customers is facilitating the emergence of new behaviors, such as showrooming and webrooming. 


\section{MONOGRÁFICO}

Given the lack of consensus in the literature on omni-channel management in retailing, this paper aims to advance the understanding of what omni-channel management in retailing is and to clarify the status quo of omni-channel research. The paper's contributions are fourfold. First, it reduces the fuzziness of the term omni-channel marketing, clearly demarcating the multi-, cross-, and omni-channel concepts. Second, it offers a consolidated overview of the current understanding of the omni-channel shopping experience and the new connected customer. Third, it proposes future lines of research related to the omni-channel strategy in retailing. Finally, it concludes with a discussion of the theoretical and practical implications of the omni-channel phenomenon and the proposal of new open questions about the topic, which has drawn considerable attention from the research community in recent years. These contributions will help retailers deepen their understanding of the need to engage in omni-channel projects and deliver superior brand experiences to consumers.

\section{Method}

The research is based on a comprehensive review of the literature on omni-channel shopping. We queried three main databases - Scopus, Google Scholar, and Web of Science - with precise keywords (omni-channel, integrated channel, bricks and clicks, omni-shopper) and screened quality journals in the fields of marketing, communication, retailing, and information systems. Beginning with the first studies by Rigby (2011), we examined a total of more than 100 papers and business reports. The analysis of the selected contributions included a critical and evaluative theoretical tracing with a view to finding an integrative approach able to improve understanding of the customer experience in the age of omni-channel shopping.

\section{Development}

\subsection{What is, and is not, omni-channel? A conceptualization}

As noted, the use of the concepts multi-, cross-, and omni-channel in academic articles is blurred (Beck \& Rygl, 2015; Klaus, 2013). Many articles use multi-channel as an umbrella term to describe different strategies, regardless of how the channels are configured. To clarify this question, this section will offer a detailed review of the main literature on the omni-channel phenomenon. 
Nowadays, customers tend to use more channels and touch-points during their shopping journey, whether in the search, purchase, or post-purchase stage (Weinberg, Parise, \& Guinan, 2007). Thus, channels are defined as the different touchpoints through which the firm and the customer interact (Mehta, Dubinsky, \& Anderson, 2002; Neslin et al., 2006). Channel management refers to the process by which a company analyzes, organizes, and controls its channels (Mehta et al., 2002). This channel management can range from the complete separation of channels to total integration with full coordination, with a wide range of gradations and strategies between the two extremes (Neslin et al., 2006). The main differences between these concepts are the different degrees to which the customer can trigger channel interaction and the retailer can control channel integration (Beck \& Rygl, 2015).

Thus, in multi-channel retailing, the retailer offers several channels as independent entities in order to align them with specific targeted customer segments (Frazer \& Stiehler, 2014; Picot-Coupey et al., 2016; Zhang et al., 2010). The next stage in the evolution of retailing is cross-channel, which includes the first attempts to integrate brick-and-mortar stores and web channels and enhance the cross-functionality between them (Cao, 2014; Cao \& Li, 2015; Harris, 2012). The final stage to date is omni-channel, which seeks to create a holistic shopping experience by merging various touch-points, allowing customers to use whichever channel is best for them at whatever stage of the customer journey they are in (Harris, 2012). Table 1 shows the main differences between these three concepts (Table1).

\begin{tabular}{|c|c|c|c|}
\hline Concept & Multi-channel & Cross-channel & Omni-channel \\
\hline $\begin{array}{c}\text { Degree of } \\
\text { integration }\end{array}$ & none & $\begin{array}{c}\text { Partial integration of } \\
\text { some channels }\end{array}$ & $\begin{array}{c}\text { Integration of all } \\
\text { widespread channels }\end{array}$ \\
\hline $\begin{array}{c}\text { Channel } \\
\text { scope }\end{array}$ & $\begin{array}{c}\text { Retail channes switching } \\
\text { between certain } \\
\text { channels and } \\
\text { touch-points }\end{array}$ & Total \\
site, and mobile & $\begin{array}{c}\text { Retail channels: store, } \\
\text { website, mobile, social } \\
\text { media, customer } \\
\text { touch-points }\end{array}$ & $\begin{array}{c}\text { Retail channels: store, } \\
\text { website, mobile, social } \\
\text { media, customer } \\
\text { touch-points }\end{array}$ \\
\hline
\end{tabular}




\section{MONOGRÁFICO}

\begin{tabular}{|c|c|c|c|}
\hline & Multi-channel & Cross-channel & Omni-channel \\
\hline $\begin{array}{l}\text { Customer } \\
\text { relationship } \\
\text { focus: } \\
\text { brand vs. } \\
\text { channel }\end{array}$ & $\begin{array}{l}\text { Customer-retail channel } \\
\text { focus }\end{array}$ & $\begin{array}{l}\text { Customer-retail channel } \\
\text { focus }\end{array}$ & $\begin{array}{c}\text { Customer-retail } \\
\text { channel-brand focus }\end{array}$ \\
\hline Objectives & $\begin{array}{c}\text { Channel objectives (sales } \\
\text { per channel, experience per } \\
\text { channel) }\end{array}$ & $\begin{array}{c}\text { By channel or } \\
\text { connected channels and } \\
\text { touch-points }\end{array}$ & $\begin{array}{l}\text { All channels work } \\
\text { together to offer a holistic } \\
\text { customer experience }\end{array}$ \\
\hline $\begin{array}{c}\text { Channel } \\
\text { management }\end{array}$ & $\begin{array}{l}\text { Per channel } \\
\text { Management of channels and } \\
\text { customer touch-points gea- } \\
\text { red toward optimizing the } \\
\text { experience with each one } \\
\text { Perceived interaction with } \\
\text { the channel }\end{array}$ & $\begin{array}{l}\text { By channel or } \\
\text { connected channels and } \\
\text { touch-points } \\
\text { Perceived partial } \\
\text { interaction with } \\
\text { the brand }\end{array}$ & $\begin{array}{l}\text { Cross-channel } \\
\text { Synergetic management of } \\
\text { the channels and custo- } \\
\text { mer touch-points } \\
\text { geared toward optimizing } \\
\text { the holistic } \\
\text { experience } \\
\text { Perceived interaction with } \\
\text { the brand }\end{array}$ \\
\hline Customers & $\begin{array}{c}\text { No possibility of triggering } \\
\text { interaction } \\
\text { Use channels in parallel }\end{array}$ & $\begin{array}{l}\text { Can trigger partial } \\
\text { interaction } \\
\text { Use channels in parallel }\end{array}$ & $\begin{array}{l}\text { Can trigger full } \\
\text { interaction } \\
\text { Use channels } \\
\text { simultaneously }\end{array}$ \\
\hline Retailers & $\begin{array}{l}\text { No possibility of controlling } \\
\text { integration of all channels }\end{array}$ & $\begin{array}{l}\text { Control partial } \\
\text { integration of all } \\
\text { channels }\end{array}$ & $\begin{array}{c}\text { Control full integration of } \\
\text { all channels }\end{array}$ \\
\hline Sales people & $\begin{array}{c}\text { Do not adapt selling beha- } \\
\text { vior }\end{array}$ & $\begin{array}{l}\text { Adapt selling behavior } \\
\text { using different } \\
\text { arguments depending } \\
\text { on the channel }\end{array}$ & $\begin{array}{l}\text { Adapt selling behavior } \\
\text { using different } \\
\text { arguments depending on } \\
\text { each customer's needs and } \\
\text { knowledge of the product }\end{array}$ \\
\hline Data & $\begin{array}{c}\text { Data are not shared across } \\
\text { channels }\end{array}$ & $\begin{array}{c}\text { Data are partially } \\
\text { shared across channels }\end{array}$ & $\begin{array}{c}\text { Data are shared across } \\
\text { channels }\end{array}$ \\
\hline
\end{tabular}

Table 1: Differences between multi-, cross-, and omni-channel retailing. Source: Based on Rigby (2011), Piotrowicz and Cuthbertson (2014), Beck and Rygl (2015), Verhoef et al. (2015), Picot-Coupey et al. (2016) and Juaneda-Ayensa et al. (2016). 
Recently, Verhoef et al. defined omni-channel management as "the synergetic management of the numerous available channels and customer touch-points intended to optimize the customer experience and performance across channels" (Verhoef et al., 2015b, p.176).

As can be seen in Figure 1, retailing is constantly evolving; the different concepts reflect this process and are connected. This evolution occurs as new communication channels and touch-points appear, in order to facilitate and personalize customers' shopping experience.

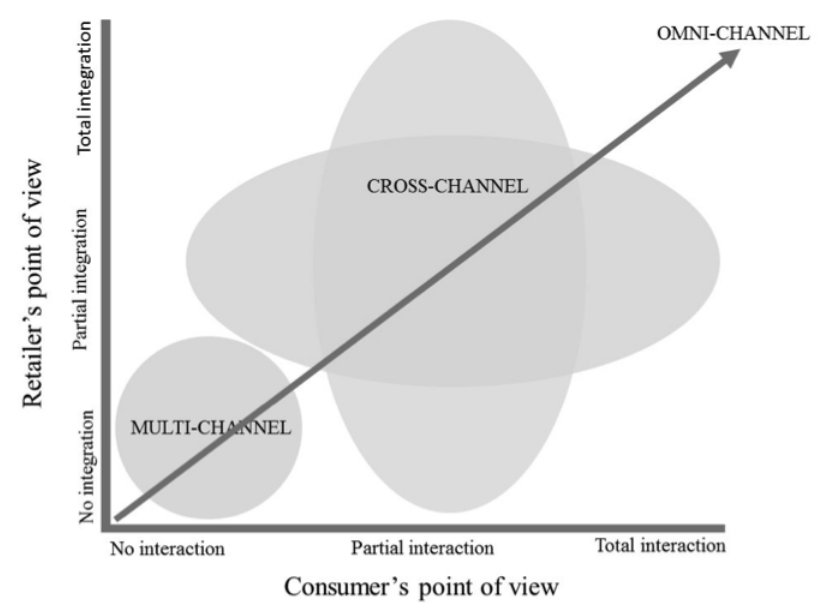

Figure 1: Evolution of retailing: Different degrees of channel and touch-point interaction/integration

From the customer's point of view, multi-channel retailing takes place when, for example, the customer cannot redeem an e-coupon at a physical store. From the retailer's viewpoint, it occurs when the retailer cannot share data across channels or integrate the inventory of the different channels. The next step in the evolution of retailing is cross-channel retailing. In this case, there may be different relationships between channel integration and interaction. For instance, a customer may receive a coupon message from the mobile shop that can be used at a physical store. Finally, in an omni-channel environment, 


\section{MONOGRÁFICO}

customers can combine different online channels and touch-points (e.g., the website, social media, and the mobile app) with the offline channel throughout their customer journey, thereby changing how they are served before, during, and after the purchase (0strom et al., 2015). For instance, shoppers might search for information on a product using the mobile app, buy the product on the website, and pick the product up or return it at a physical store. As this example illustrates, consumers can switch between channels without interrupting their transaction stage. From the retailer's viewpoint, if the retailer can share customer information, inventory, or pricing across all channels, then the channels are fully integrated, and the brand is carrying out a complete omni-channel strategy (Beck \& Rygl, 2015).

\subsection{An integrative omni-channel framework}

Omni-channel strategy refers to an ideal strategy that offers several channels in accordance with the latest technological developments and current consumer behavior (Verhoef et al., 2015b; Zhang et al., 2010). Omni-channel marketing is characterized by the use of a customer-centric approach with a view to offering consumers a holistic shopping experience (Gupta, Lehmann, \& Stuart, 2004; Hansen \& Sia, 2015; Shah, Rust, Parasuraman, Staelin, \& Day, 2006) by allowing them to use several consumer-store interaction channels simultaneously (e.g., use of mobile Internet access in a physical retail store to research products and/or compare prices) (Lazaris \& Vrechopoulos, 2014; Verhoef et al., 2015b).

Another difference with regard to multi-channel retailing is that the barriers between channels are blurred. If all channels are connected, customers can start their journey on one channel and complete it on another, resulting in a seamless experience that increases convenience and engagement and ensures a consistent brand experience (Eaglen, 2013). Finally, omni-channel management is also related to data integration. It offers new potential data sources, particularly via mobile channels and social media. This provides an unprecedented opportunity to understand not just customer transactions but also customer interactions, such as store visits, Facebook likes, website searches, or check-ins at nearby establishments. 
The limitation is no longer the lack of data, but the ability to analyze the data obtained (Brynjolfsson et al., 2013). If a brand is able to integrate all the information on each customer, it can provide him or her with a personalized experience. Retailers need to understand who their customers are, know what they like, deliver what they need, and reach them through their preferred channels in order to achieve greater customer loyalty (Melero et al., 2016).

However, previous studies have identified negative aspects of multi-channel retailing, such as cannibalization and free-riding behavior (Heitz-Spahn, 2013). According to Peltola et al. (2015), there are two keys to providing a good omni-channel experience that prevents such behavior: reducing the risk of losing customers during the customer journey by providing a unified, integrated service and customer experience; and encouraging customers to stay with the company as they proceed in their customer journey by providing seamless and intuitive transitions across channels at each touch-point to accommodate their preferences, needs, and behavior.

This new form of retailing is not equally developed in all industries. The fashion, travel, and financial service industries have begun to implement this strategy with good results (Gao \& Yang, 2016; Harvey, 2016; Verhoef et al., 2015b). The major challenge for retailers when it comes to implementing a good omni-channel strategy is to determine how to offer their customers a superior shopping experience throughout the shopping journey. To achieve this goal, companies should define an integrated strategy in accordance with their industry, determining what is required to embrace mobile technology, unify pricing and product information, unify customer communications, integrate supply chain management and make it more flexible, and ensure integrated data management.

\subsection{Enhancing the customer experience in an omni-channel environment}

We live in a customer-driven world, where the informed customer, not the retailer, dictates much of the desired content. Retailers can no longer passively stand by and hope their product content finds the right shopper. 
These new customers are connected customers, who want to have multiple possibilities for interacting with the company throughout the shopping journey and expect a superior shopping experience (Cook, 2014). They want to use all channels simultaneously, not each channel in parallel (Lazaris \& Vrechopoulos, 2014), because they do not think of channels in isolation but rather combine them and make decisions based on their mood and lifestyle demands (Blázquez, 2014).

They have specific characteristics that make them special: on average, they spend more money (Venkatesan, V Kumar, \& Ravishanker, 2007), buy more frequently (Kumar \& Venkatesan, 2005), and have a longer customer lifetime value (Scott A. Neslin \& Shankar, 2009) than conventional shoppers. However, they are also more demanding and expect more from their shopping experiences (Mathwick, Malhotra, \& Rigdon, 2002). Their shopping behavior is more exploratory, as they seek more variety than consumers who buy in a single channel (Kumar \& Venkatesan, 2005; Rohm \& Swaminathan, 2004). Thus, the customer journey for these new omni-shoppers is less linear or fixed and more fluid due to their use of different channels and touch-points to research, locate, and purchase products (Aubrey \& Judge, 2012). Furthermore, omni-channel customers do not use these different touch-points in any particular chronological order during the five-stage consumer decision-making process (need recognition, information search, evaluation of alternatives, purchase decision, and post-purchase behavior) (Engel, Blackwell, \& Miniard, 1985). In order to offer a superior experience, retailers should thus embrace new technologies that help deliver a holistic shopping process to customers, making it possible to personalize content and make special offers and recommendations to each customer in order to enhance the experience.

As already noted, technology has been a catalyst in changing consumer attitudes and behaviors (Aubrey \& Judge, 2012). Technological developments are the primary drivers for companies to adopt an omni-channel strategy (Ansari, Mela, \& Neslin, 2008), specifically: smart mobile devices (smartphones and tablets), related software and services (apps, mobile payments, e-coupons, digital flyers, and location-based services) (Aubrey \& Judge, 2012; Brynjolfs- 
son et al., 2013; Hansen \& Sia, 2015; Piotrowicz \& Cuthbertson, 2014; Verhoef et al., 2015b), and social media (Hansen \& Sia, 2015; Piotrowicz \& Cuthbertson, 2014). In this sense, Bodhani investigated how digital technologies can reinvent retail shopping and concluded that stores will become a place for brand and consumer experiences and new technologies (Bodhani, 2012). In an omni-channel environment, mobile technologies are crucial due to the gap between offline and online channels. Mobile devices can bridge that gap by bringing the online experience into the brick-and-mortar store. In addition, the combination of interactive and entertaining technologies attracts more consumers and improves the shopping experience (Demirkan \& Spohrer, 2014; Pantano \& Viassone, 2015; Papagiannidis, Pantano, See-To, \& Bourlakis, 2013; Poncin \& Ben Mimoun, 2014). The growing role of in-store technologies also creates an additional dimension. This includes technologies for customers such as free WiFi, interactive screens, augmented reality, virtual mirrors/fitting rooms, digital signage, beacons, intelligent self-service kiosks, and QR codes, in addition to customers' own mobile devices. There are also technologies for staff, such as tablets or touch screens to help sellers in different ways during the buying process (Piotrowicz \& Cuthbertson, 2014), e.g., by enabling them to answer customers' questions by showing them videos, reviews, or previous customers' opinions or to track inventory in all stores in real time through RFID tags. However, due to the growth of new technologies and the potential for customer saturation, retailers must focus on technology that is relevant for consumers and that really provides value (Blázquez, 2014). In this regard, retailers should aim to unify customer information, product availability, product information, and pricing at all touch-points across all channels.

These technological developments have helped change the nature of customer-retailer interactions, giving rise to new shopping behaviors. Two of the most common omni-channel behaviors are showrooming and webrooming. The first is defined by Rapp et al. as the practice of "using mobile technology while in-store to compare products for potential purchase via any number of channels" (Rapp et al., 2015, p.360). It usually takes place during the product evaluation stage, when the product's physical attributes are important and an in-person evaluation can reduce the perceived risk of purchase, even if the 
purchase itself is ultimately made online (Wolny \& Charoensuksai, 2014). In response, retailers have started to engage in reverse showrooming, wherein they encourage brick-and-mortar consumers to research their products online in the store, through kiosks or mobile apps, thereby increasing the likelihood of keeping the sale (Parise, Guinan, \& Kafka, 2016). At the other end of the spectrum, webrooming occurs when shoppers compare prices, features, opinions, and guarantees online, but ultimately make the purchase offline (Wolny \& Charoensuksai, 2014). This behavior occurs mainly once the initial product selection has been made.

In order to mitigate such behaviors, brands are starting to offer their customers solutions that combine the best of both online and offline shopping. Retailers are redefining the brand experience through new formats such as "clickand-collect," "delivery in 24 hours," "in-store ordering, home delivery," "order online, return to store," "click in store," and other combinations of online and traditional retail activities that facilitate and improve the shopping process and the customer experience (Bell et al., 2014).

\section{Conclusions}

Given the lack of consensus in the academic literature about omni-channel marketing, and its novelty and importance in today's retail world, this paper has sought to advance the understanding of omni-channel retail. At the same time, it has sought to identify emerging consumer purchasing behaviors during the customer journey, thereby helping to enhance knowledge about this topic from a managerial and theoretical perspective. The study took a multidisciplinary approach because the omni-channel phenomenon has been studied in a variety of fields, including marketing (Beck \& Rygl, 2015; Cook, 2014; Cummins, Peltier, \& Dixon, 2016; Juaneda-Ayensa et al., 2016; Lazaris \& Vrechopoulos, 2014; Melero et al., 2016; Scott A. Neslin et al., 2014), e-commerce (Bell et al., 2014; Gao \& Yang, 2016; Piotrowicz \& Cuthbertson, 2014; Weill \& Woerner, 2015), retailing (Picot-Coupey et al., 2016; Rigby, 2011; Verhoef et al., 2015b; Yurova, Rippé, Weisfeld-Spolter, Sussan, \& Arndt, 2016), and information systems and technology (Chopra, 2015; Tetteh \& Qi, 2014). 
New technologies allow retailers to integrate all the information that today's emerging channels and touch-points provide, giving rise to the phenomenon known as omni-channel (Brynjolfsson et al., 2013; Dimitrova \& Rosenbloom, 2010; Lewis, Whysall, \& Foster, 2014; Schramm-Klein, Wagner, Steinmann, \& Morschett, 2011; Seck \& Philippe, 2013). Omni-channel strategy refers to a customer management strategy applied throughout the lifecycle of the customer's relationship with the company (Juaneda-Ayensa et al., 2016). Under this strategy, the retailer ensures coherent and consistent communication across the various channels and touch-points customers may wish to use to interact with the company at any given time, mainly the physical store, the online channel, the mobile channel, and social media. In this regard, as shown in Figure 1, the boundaries between multi-, cross-, and omni-channel are blurred. In fact, they are not distinct, isolated strategies, but rather an evolution that depends on the degree of integration customers perceive between channels and the ease with which they can interact with the brand across these channels and touch-points during the shopping journey (Bendoly, Blocher, Bretthauer, Krishnan, \& Venkataramanan, 2005). Omni-channel, understood as total integration for retailers and consumers, is a goal to pursue in a continuous strategic line that is difficult to fully achieve.

In terms of managerial implications, retailers should focus on two main aspects: 1) creating a holistic customer experience and 2) making an effective technology investment.

1. Companies must learn to build a shopping experience for consumers and store data on it. They must not limit themselves to one-size-fits-all customer relationship management. As a result of the many channels used today (social media, physical store, and mobile applications), companies have a lot of consumer information. They must use it to customize and ensure the consistency of each customer relationship. Retailers have to know what the customer's shopping experience is like in order to manage, analyze, and optimize it. That, in turn, requires total integration of the channels. Customers want to engage with the brand; they do not care which channel they use, but they want continuous management. In other words, they want to be able to buy a product in the online shop, pick it up at a physical store, 
notify the retailer via their favorite social media platform that in the end they would rather have it shipped to their home, and be able to return it to a physical store because they would prefer a different color and have determined through the mobile application which stores have it in their size. And they want to do all of this effortlessly, without having to start the purchase process over again each time they switch platforms. For all these reasons, companies need to know who their customers are and what they want, and they should use this information to build a customer experience that leads to loyalty. Integrating the in-store, mobile, social, and web customer data into a single intelligent business system able to identify the best offers and deliver a custom, one-to-one experience should be the ultimate goal.

2. Not all clients expect the same experience from their shopping journey; on the contrary, it depends on the specific customer and the product or service type (utilitarian or hedonic). In this regard, companies should identify the right combination of technologies for their industry. Effectively maximizing the benefits of the omni-channel strategy requires embracing mobile technology, unifying pricing and product information, and integrating supply chain and data management (Brynjolfsson et al., 2013; Peltola et al., 2015; Weatherly, n.d.; Weill \& Woerner, 2015). In-store technology is essential to enhance a superior shopping experience, and its acceptance and use depends on customer innovativeness, ease of use, and usefulness (Juaneda-Ayensa et al., 2016). Stores should support their customers' desire for connectivity throughout the customer journey, especially the in-store use of smartphones to make shopping easier (Aubrey \& Judge, 2012). In addition, the role of store staff may need to change. Although staff certainly need to be able to help shoppers use these in-store technologies, they also need to act as advisors and curators for shoppers, for instance, by offering them feedback on how they look in specific items and providing them with different options (Parise et al., 2016).

From a theoretical perspective, omni-channel retailing is still in its infancy. Although increasingly agile, it requires further research. To this end, several future lines of research should be considered (Table 2). 


\begin{tabular}{|c|c|c|}
\hline Topic & Open questions & Authors \\
\hline Conceptualization & $\begin{array}{l}\text { How does the type of industry, company, } \\
\text { or product influence the omni-channel } \\
\text { strategy? } \\
\text { Is omni-channel management (always) } \\
\text { desirable? } \\
\text { How can companies achieve a unified } \\
\text { view of the customer across channels? } \\
\text { How can omni-channel management in- } \\
\text { crease customer loyalty? }\end{array}$ & $\begin{array}{c}\text { Verhoef et al. (2015) } \\
\text { Piotrowicz \& Cuthbertson (2014) } \\
\text { Own }\end{array}$ \\
\hline $\begin{array}{c}\text { Channel, technology, } \\
\text { and performance }\end{array}$ & $\begin{array}{l}\text { Can different customer touch-points and } \\
\text { channels be integrated in such a way as } \\
\text { to enhance channel performance? } \\
\text { How do specific customer touch-points } \\
\text { impact the performance of retail channels? } \\
\text { How does in-store use of mobile } \\
\text { channels/touch-points affect purchase } \\
\text { behavior and store performance? } \\
\text { What is the role of mobile devices in the } \\
\text { omni-channel environment? } \\
\text { How can companies exploit the in-store } \\
\text { possibilities of mobile channels with } \\
\text { regard to omni-channel retailing? } \\
\text { How can technology affect purchase } \\
\text { intention? And purchase behavior? }\end{array}$ & $\begin{array}{c}\text { Verhoef et al. (2015) } \\
\text { Aubrey \& Judge (2012) } \\
\text { Piotrowicz \& Cuthbertson (2014) } \\
\text { Brynjolfsson et al. (2013) }\end{array}$ \\
\hline Customer experience & $\begin{array}{l}\text { What is required to provide a seamless } \\
\text { omni-channel customer experience? } \\
\text { What does the client expect of tech- } \\
\text { nology in the different phases of the } \\
\text { shopping journey? } \\
\text { How should brands design in-store } \\
\text { experiences? } \\
\text { How do interactive technologies shape } \\
\text { customer experience? }\end{array}$ & $\begin{array}{c}\text { Hansen \& Sia (2015) } \\
\text { Trenz (2015) }\end{array}$ \\
\hline
\end{tabular}




\section{MONOGRÁFICO}

\begin{tabular}{|c|c|c|}
\hline Topic & Open questions & Authors \\
\hline $\begin{array}{l}\text { Retail mix across } \\
\text { channels }\end{array}$ & $\begin{array}{l}\text { To what extent should retailers really } \\
\text { strive for integration in their retail mix } \\
\text { in the different channels and } \\
\text { touch-points they use? } \\
\text { What role should the brand play in } \\
\text { directing this integration? } \\
\text { To what extent should shoppers control } \\
\text { this integration (i.e., customized } \\
\text { strategies for shoppers)? } \\
\text { What is the effect of different marketing } \\
\text { mix instruments (i.e., promotions) used } \\
\text { across touch-points and channels on } \\
\text { channel performance? } \\
\text { What drives showrooming behavior in shop- } \\
\text { pers? How can retailers "push back" against } \\
\text { or benefit from this behavior? } \\
\text { What role should personalization/customi- } \\
\text { zation of the omni-channel retail mix play? } \\
\text { What role does social media play in the } \\
\text { omni-channel environment? } \\
\text { What is the trade-off between } \\
\text { convenience and privacy? }\end{array}$ & $\begin{array}{l}\text { Verhoef et al. (2015) } \\
\text { Lazaris \& Vrechopoulos (2014) } \\
\text { Piotrowicz \& Cuthbertson (2014) }\end{array}$ \\
\hline $\begin{array}{l}\text { Omni-channel retail } \\
\text { store atmosphere }\end{array}$ & $\begin{array}{l}\text { What is the new role of the physical } \\
\text { store in an omni-channel environment? }\end{array}$ & Lazaris et al. (2015) \\
\hline Salespeople & $\begin{array}{l}\text { What sales techniques are most } \\
\text { effective for use by salespeople in an } \\
\text { omni-channel environment? }\end{array}$ & Lazaris \& Vrechopoulos (2014) \\
\hline
\end{tabular}




\begin{tabular}{|c|c|c|}
\hline Topic & Open questions & Authors \\
\hline Shopper behavior & $\begin{array}{l}\text { What drives customers to use multiple } \\
\text { touch-points and channels } \\
\text { simultaneously? } \\
\text { Do specific touch-points create } \\
\text { preferences for and lead to the choice of } \\
\text { specific retail channels? } \\
\text { What are the interrelationships between } \\
\text { a customer's touch-point choice and } \\
\text { that same customer's retail channel } \\
\text { choice? } \\
\text { How does the brand choice process } \\
\text { differ by channel and vice versa? } \\
\text { To what extent is forward-looking } \\
\text { behavior involved in brand/channel choice? } \\
\text { What is the role of social influence on } \\
\text { brand/channel choice? } \\
\text { What role do loyalty and free-riding } \\
\text { behavior play in omni-channel settings? }\end{array}$ & $\begin{array}{l}\text { Juaneda-Ayensa et al. (2016) } \\
\text { Verhoef et al. (2015) } \\
\text { Neslin et al. (2014) } \\
\text { Lazaris \& Vrechopoulos (2014) }\end{array}$ \\
\hline Omni-shoppers & $\begin{array}{l}\text { Can shoppers be classified and profiled } \\
\text { according to the intensity of their use } \\
\text { of omni-channel practices? } \\
\text { Do omni-channel shoppers contribute } \\
\text { more to sales revenue? } \\
\text { Who are omni-channel shoppers and } \\
\text { what do they want? }\end{array}$ & $\begin{array}{c}\text { Lazaris \& Vrechopoulos (2014) } \\
\text { Cook }(2014)\end{array}$ \\
\hline
\end{tabular}

Table 2: Open questions about omni-channel retailing

\section{References}

Ansari, A., Mela, C. F., \& Neslin, S. a. (2008). Customer Channel Migration. Journal of Marketing Research, 45(1), 60-76. http://doi.org/10.1509/jmkr.45.1.60 Aubrey, C., \& Judge, D. (2012). Re-imagine retail: Why store innovation is key to a brand's growth in the "new normal", digitally-connected and transparent world. Journal of Brand Strategy, 1(1), 31-39. 


\section{MONOGRÁFICO}

Beck, N., \& Rygl, D. (2015). Categorization of multiple channel retailing in Multi-, Cross-, and Omni-Channel Retailing for retailers and retailing. Journal of Retailing and Consumer Services, 27, 170-178. http://doi.org/10.1016/j. jretconser.2015.08.001

Bell, B. D. R., Gallino, S., \& Moreno, A. (2014). How to Win in an Omnichannel World. MIT Sloan Management Review, 56(1), 45-54.

Bendoly, E., Blocher, J. D., Bretthauer, K. M., Krishnan, S., \& Venkataramanan, M. A. (2005). Online/In-Store Integration and Customer Retention. Journal of Service Research, 32(3), 313-327. http://doi.org/10.1177/1094670504273964 Blázquez, M. (2014). Fashion Shopping in Multichannel Retail: The Role of Technology in Enhancing the Customer Experience. International Journal of Electronic Commerce, 18(4), 97-116. http://doi.org/10.2753/JEC10864415180404

Bodhani, A. (2012). Shops offer the e-tail experience. Engineering \& Technology, 7(5), 46-49. http://doi.org/10.1049/et.2012.0512

Brynjolfsson, E., Hu, Y. J., \& Rahman, M. S. (2013). Competing in the Age of Omnichannel Retailing. MIT Sloan Management Review, 54(4), 23-29.

Cao, L. (2014). Business Model Transformation in Moving to a Cross-Channel Retail Strategy: A Case Study. International Journal of Electronic Commerce, 18(4), 69-96. http://doi.org/10.2753/JEC1086-4415180403

Cao, L., \& Li, L. (2015). The Impact of Cross-Channel Integration on Retailers' Sales Growth. Journal of Retailing, 91(2), 198-216. http://doi.org/10.1016/j. jretai.2014.12.005

Chopra, S. (2015). How omni-channel can be the future of retailing. Decision, 43(2), 135-144. http://doi.org/10.1007/s40622-015-0118-9

Cook, G. (2014). Customer experience in the omni-channel world and the challenges and opportunities this presents. Journal of Direct, Data and Digital Marketing Practice, 15(4), 262-266. http://doi.org/10.1057/dddmp.2014.16

Cummins, S., Peltier, J., \& Dixon, A. (2016). Omni-channel research framework in the context of personal selling and sales management : a review and research extensions. Journal of Research in Interactive Marketing, 10(1), 2-16. http:// doi.org/10.1108/JRIM-12-2015-0094 
Demirkan, H., \& Spohrer, J. (2014). Developing a framework to improve virtual shopping in digital malls with intelligent self-service systems. Journal of Retailing and Consumer Services, 21(5), 860-868. http://doi.org/10.1016/j. jretconser.2014.02.012

Dimitrova, B., \& Rosenbloom, B. (2010). Standardization Versus Adaptation in Global Markets: Is Channel Strategy Different? Journal of Marketing Channels, 17(2), 157-176. http://doi.org/10.1080/10466691003635127

Eaglen, M. (2013). Omni-channel retail: joining up the consumer experience | Media Network | The Guardian.

Engel, J. F., Blackwell, R. D., \& Miniard, P. W. (1985). Consumer Behavior. Journal of Consumer Research (Vol. 12). Retrieved from http://www.regent.edu/acad/ global/cur/doc/620/mrkt_txt.pdf

Frazer, M., \& Stiehler, B. E. (2014). Omnichannel Retailing: the Merging of the Online and Off-Line Environment. Global Conference on Business and Finance Proceedings, 655-657. Retrieved from https://goo.gl/n98ujh

Gao, R., \& Yang, Y. (2016). Consumers ' Decision : Fashion Omni-channel Retailing, $7(2), 325-342$.

Gupta, S., Lehmann, D. R., \& Stuart, J. A. (2004). Valuing Customers. Journal of Marketing Research, 41(1), 7-18. http://doi.org/10.1509/jmkr.41.1.7.25084

Hansen, R., \& Sia, S. K. (2015). Hummel's Digital Transformation Toward Omnichannel Retailing: Key Lessons Learned. MIS Quarterly Executive, 14(2), 51-66. Retrieved from http://search.ebscohost.com/login.aspx?direct=true\&d $\mathrm{b}=\mathrm{buh} \& \mathrm{AN}=102933798 \&$ site $=$ ehost-live

Harris, E. (2012). A Look At Omni-Channel Retailing.

Harvey, D. (2016). Digital transformation in banks: The trials, opportunities and a guide to what is important. Journal of Digital Banking, 1(2), 136-145.

Heitz-Spahn, S. (2013). Cross-channel free-riding consumer behavior in a multichannel environment_An investigation of shopping motives, sociodemographics and product categories. Journal of Retailing and Consumer Services, 20(6), 570-578. http://doi.org/10.1016/j.jretconser.2013.07.006

Juaneda-Ayensa, E., Mosquera, A., \& Sierra Murillo, Y. (2016). Omnichannel Customer Behavior: Key Drivers of Technology Acceptance and Use and Their Effects on Purchase Intention. Frontiers in Psychology, 7(July). http://doi.org/10.3389/ fpsyg.2016.01117 


\section{MONOGRÁFICO}

Klaus, P. (2013). Exploring online channel management strategies and the use of social media as a market research tool. International Journal of Market Research.

Kumar, V., \& Venkatesan, R. (2005). Who are the multichannel shoppers and how do they perform?: Correlates of multichannel shopping behavior. Journal of Interactive Marketing. http://doi.org/10.1002/dir.20034

Lazaris, C., \& Vrechopoulos, A. (2014). From Multichannel to "Omnichannel" Retailing: Review of the Literature and Calls for Research. In 2nd International Conference on Contemporary Marketing Issues (ICCMI). Athens, Greece. http:// doi.org/10.13140/2.1.1802.4967

Lazaris, C., Vrechopoulos, A., Doukidis, G., \& Fraidaki, K. (2015). The Interplay of Omniretailing Store Atmosphere on Consumers Purchase Intention towards the Physical Retail Store. In 12th European, Mediterranean \& Middle Eastern Conference on Information Systems (EMCIS). Athens, Greece. http://doi. org/10.13140/RG.2.1.3928.3048

Lewis, J., Whysall, P., \& Foster, C. (2014). Drivers and Technology-Related Obstacles in Moving to Multichannel Retailing. International Journal of Electronic Commerce, 18(4), 43-68. http://doi.org/10.2753/JEC1086-4415180402

Mathwick, C., Malhotra, N. K., \& Rigdon, E. (2002). The effect of dynamic retail experiences on experiential perceptions of value: An Internet and catalog comparison. Journal of Retailing, 78(1), 51-60. http://doi.org/10.1016/S0022-4359(01)00066-5

Mehta, R., Dubinsky, A. J., \& Anderson, R. E. (2002). Marketing channel management and the sales manager. Industrial Marketing Management, 31(5), 429-439. http://doi.org/10.1016/S0019-8501(01)00159-6

Melero, I., Sese, F., \& Verhoef, P. C. (2016). Recasting the Customer Experience in Today's 0mni-channel Environment. Universia Business Review, 0(50), 18-37. http://doi.org/10.3232/UBR.2016.V13.N2.01

Neslin, S. A., Grewal, D., Leghorn, R., Shankar, V., Teerling, M. L., Thomas, J. S., \& Verhoef, P. C. (2006). Challenges and Opportunities in Multichannel Customer Management. Journal of Service Research, 9(2), 95-112. http://doi. org/10.1177/1094670506293559

Neslin, S. A., Jerath, K., Bodapati, A., Bradlow, E. T., Deighton, J., Gensler, S., ... Zhang, Z. J. (2014). The interrelationships between brand and channel choice. Marketing Letters, 25(3), 319-330. http://doi.org/10.1007/s11002-014-9305-2 
Neslin, S. A., \& Shankar, V. (2009). Key Issues in Multichannel Customer Management: Current Knowledge and Future Directions. Journal of Interactive Marketing, 23(1), 70-81. http://doi.org/10.1016/j.intmar.2008.10.005

Ostrom, A., Parasuraman, A., Bowen, D., Patrício, L., Voss, C., \& Lemon, K. (2015). Service Research Priorities in a Rapidly Changing Context. Journal of Service Research, 18(2), 127-159.

Pantano, E., \&Viassone, M. (2015). Engaging consumers on newintegrated multichannel retail settings: Challenges for retailers. Journal of Retailing and Consumer Services, 25, 106-114. http://doi.org/10.1016/j.jretconser.2015.04.003

Papagiannidis, S., Pantano, E., See-To, E. W. K., \& Bourlakis, M. (2013). Modelling the determinants of a simulated experience in a virtual retail store and users' product purchasing intentions. Journal of Marketing Management, 29(13-14), 1462-1492. http://doi.org/10.1080/0267257X.2013.821150

Parise, S., Guinan, P., \& Kafka, P. (2016). Solving the crisis of immediacy: How digital technology can transform the customer experience. Business Horizons, 59(4), 411-420. http://doi.org/10.1016/j.bushor.2016.03.004

Peltola, S., Vainio, H., \& Nieminen, M. (2015). Key Factors in Developing Omnichannel Customer Experience with Finnish Retailers. In HCI in Business (pp. 335-346). Springer International Publising. Retrieved from http://link.springer.com/ chapter/10.1007/978-3-319-20895-4_31

Picot-Coupey, K., Huré, E., \& Piveteau, L. (2016). Channel design to enrich customers' shopping experiences-Synchronizing clickswith bricksinanomni-channelperspective - the Direct Optic case. International Journal of Retail \& Distribution Management, 44(3), 336-368. http://doi.org/http://dx.doi.org/10.1108/09564230910978511

Piotrowicz, W., \& Cuthbertson, R. (2014). Introduction to the Special Issue Information Technology in Retail: Toward Omnichannel Retailing. International Journal of Electronic Commerce, 18(4), 5-16. http://doi.org/10.2753/JEC1086-4415180400

Poncin, I., \& Ben Mimoun, M. S. (2014). The impact of e-atmospherics on physical stores. Journal of Retailing and Consumer Services, 21(5), 851-859. http://doi. org/10.1016/j.jretconser.2014.02.013

Rapp, A., Baker, T. L., Bachrach, D. G., Ogilvie, J., \& Beitelspacher, L. S. (2015). Perceived customer showrooming behavior and the effect on retail salesperson self-efficacy and performance. Journal of Retailing, 91(2), 358-369. http:// doi.org/10.1016/j.jretai.2014.12.007 
Rigby, D. (2011). The future of shopping. Harvard Business Review, 89(12), 65-76. Rohm, A. J., \& Swaminathan, V. (2004). A typology of online shoppers based on shopping motivations. Journal of Business Research, 57(7), 748-757. http:// doi.org/10.1016/S0148-2963(02)00351-X

Schramm-Klein, H., Wagner, G., Steinmann, S., \& Morschett, D. (2011). Crosschannel integration - is it valued by customers? The International Review of Retail, Distribution and Consumer Research, 21(5), 501-511. http://doi.org/1 0.1080/09593969.2011.618886

Seck, A. M., \& Philippe, J. (2013). Service encounter in multi-channel distribution context: virtual and face-to-face interactions and consumer satisfaction. The Service Industries Journal, 33(6), 565-579. http://doi.org/10.1080/02642069.2011.622370

Shah, D., Rust, R. T., Parasuraman, A., Staelin, R., \& Day, G. S. (2006). The Path to Customer Centricity. Journal of Service Research, 9(2), 113-124. http://doi. org/10.1177/1094670506294666

Tetteh, A., \& Qi, X. (2014). Supply Chain Distribution Networks: Single-, Dual-, \& Omni-Channel. Interdisciplinary Journal of Research in Business, 3(9), 63-73. Retrieved from http://idjrb.com/articlepdf/2014_issue9/4.pdf

Trenz, M. (2015). The blurring line between electronic and physical channels: Reconceptualising multichannel commerce. In 23rd European Conference on Information Systems (ECIS). Muesnter, Germany.

Venkatesan, R., V Kumar, \& Ravishanker, N. (2007). Multichannel Shopping: Causes and Consequences. Journal of Marketing, 71, 114-132.

Verhoef, P. C., Kannan, P. K., \& Inman, J. J. (2015a). From Multi-Channel Retailing to Omni-Channel Retailing. Journal of Retailing, 91(2), 174-181. http://doi. org/10.1016/j.jretai.2015.02.005

Verhoef, P. C., Kannan, P. K., \& Inman, J. J. (2015b). From Multi-Channel Retailing to Omni-Channel Retailing: Introduction to the Special Issue on Multi-Channel Retailing. Journal of Retailing, 91(2), 174-181. http://doi.org/10.1016/j. jretai.2015.02.005

Weatherly, J. (n.d.). The State of the Omni Channel.

Weill, P., \& Woerner, S. L. (2015). Thriving in an Increasingly Digital Ecosystem. MIT Sloan Management Review, 56(4), 27-34. Retrieved from http://mitsmr. com/1BkdvAq 
Weinberg, B. D., Parise, S., \& Guinan, P. J. (2007). Multichannel marketing: Mindset and program development. Business Horizons, 50(5), 385-394. http://doi. org/10.1016/j.bushor.2007.04.002

Wolny, J., \& Charoensuksai, N. (2014). Mapping customer journeys in multichannel decision-making. Journal of Direct, Data and Digital Marketing Practice, 15(4), 317-326. http://doi.org/10.1057/dddmp.2014.24

Yurova, Y., Rippé, C. B., Weisfeld-Spolter, S., Sussan, F., \& Arndt, A. (2016). Not all adaptive selling to omni-consumers is influential: The moderating effect of product type. Journal of Retailing and Consumer Services. http://doi. org/10.1016/j.jretconser.2016.01.009

Zhang, J., Farris, P. W., Irvin, J. W., Kushwaha, T., Steenburgh, T. J., \& Weitz, B. A. (2010). Crafting integrated multichannel retailing strategies. Journal of Interactive Marketing, 24(2), 168-180. http://doi.org/10.1016/j.intmar.2010.02.002

\section{Acknowledgement}

This work was funded by the Chair in Commerce at the University of La Rioja (Spain). A. M. would also like to acknowledge a research trainee (FPI) grant from the regional government of La Rioja (C.A.R.). 